\title{
Multiple Criteria Decision Making Technique in New Product Development Management
}

\author{
Alireza Mamaghani \\ Young Researchers Club, Central Tehran Branch \\ Islamic Azad University, Tehran, Iran \\ Tel: 98-21-6691-9592Ｅ-mail: ar.mamaghani@gmail.com \\ Accepted: May 17, 2012 Published: July 1, 2012 \\ URL: http://dx.doi.org/10.5296/jmr.v4i3.1753
}

Received: May 1, 2012

doi:10.5296/jmr.v4i3.1753

\begin{abstract}
Although New Product Development Management (NPDM) is a new successful, challengeable and important strategy in modern companies, understanding the key success factors in this approach is not only helpful, but also productive in reducing managerial decision-making risks. In this paper, after expanding the related literature review, consulting with teachers, administrators and experts on identifying key factors affecting NPD, the researcher provided the basic questionnaire, and then identified key success factors and their indicators in NPD process management. In the next step 20 experts and managers were asked to fill out a questionnaire according to analytical hierarchy process (AHP) approach in which all key factors and their indicators were ranked by Expert Choice software based on Cooper NPD stage-gate model and all gapes between present and ideal conditions with managerial approach were analyzed by utilizing gape comparison test. Findings showed that improving competitive position, reducing managerial and production failure risks and enhancing success of the NPD process in this company would improve NPDM by determination of priorities and identification of the key factors in SHOKA.
\end{abstract}

Keywords: New Product, Key NPD Success Factors, New Product Development Management. 


\section{Introduction}

All companies for better relationship, response to customer needs and adapt with environmental changes, want to modify their production. Furthermore, companies do the New Product Development by considering the needs and demands of the customers in different markets, to satisfy their needs, make the long-term business permanent and decrease economical risks (Ansary \& Mamaghani, 2011,p.100-122). Studies have shown that innovations to produce new products for the companies is three years on average and the cost equals approximately $\% 27.5$ of the companies' first productions until the end of the selling process (American Productivity and Quality Center, 2003; Cooper \& Schendel, 2003).

The number of NPD Goals can be fulfill customers' needs, compatibility with the market conditions, environmental changes, increasing benefits, customer satisfaction and confrontation with the policies of the competitors. This approach is considered as the main strategy for market competition. Thus, the customers were assumed to identify and rank the key factors and indicators for planners. Therefore, they would create a competitive strategy and make decisions about new products with lower costs and risks.

In contrast to developed countries in which a lot of researches have been done in order to identify key factors and determine the importance of new product development strategies for managers to understand NPD characteristics and NPD's industries' competitions and so, in developing countries it would be more competitive. Meanwhile, there are many advantages such as; human resources, high amount of cost, raw materials and investment in the Product development. Consequently, nowadays NPD is regarded as a new approach in creating customer' satisfaction with the current products and is assumed as a major principle in creating values for the customer. Moreover, NPD strategy encourages producers to launch their products in different markets with market penetration and try to have appropriate flexibility in the development of the market. Therefore, SHOKA manufacture company, state-of-the- art facilities, and lustrous background of successful experience in More than 75 products in the field of machine tools systems is the country's leading manufacturer of machinery equipment and systems, while a forceful R\&D center boosts the Industry with "set-by-order" projects as well as a stream of new products.

Experts made decision-making on NPD in SHOKA and managers who decided to represent a decision making tree through Analyzes Hierarchal Process (AHP) in order to rank all effective managerial factors and indexes for the current and the ideal NPD conditions.

Therefore, the present study was an attempt to answer the following research questions:

- What kinds of factors or indicators may affect SHOKA NPD processes?

- How are their priorities in managerial decision-making viewed by multiple criteria decision-making models?

- How can we reduce the gap between the ideal and the current-status for success in decision making in NPDM processes in SHOKA? 


\subsection{Empirical Background}

$\mathrm{Mu}$ et al (2007) investigated 74 companies in china and they found that four factors were common in NPD in any industry, but indicators were varied. Then results showed that technological, marketing, NPD team management and commercialization are important factors on NPD process decision-making ( $\mathrm{Mu}$ et al, 2007). During a systematic research, Cooper ((a), 1997) surveyed failure and success of 100 durable chemical product launch and product development in 20 years from 350 companies in Europe and North America. The results showed that some factors such as: NPD's management team, technology (technology success, the value of technology and reducing cost); marketing (customer needs, time of production, profit, market share, economic impact on the customer and creating value for customers) and commercialization with index of getting the company to have competitive products which would have been important in NPD success process. The impact of risk management strategy on NPD's performance, which was evaluated in 217 electronic telecommunication companies in China, demonstrated that; technology, marketing and management decision risks are integrative and are the top three factors that have positive influence on NPD success ( $\mathrm{Mu}$ et al, 2008). Research in telecommunications companies during five-year showed that, when NPD commercialization risk decreases by 23 percent, some new technologies to produce new products are created based on the voice of the customers (V.C) (Hyun, 2010). Another study was conducted in order to investigate the telecommunication companies in South Korea. The results indicated that cost in alpha testing would be reduced to 43 percent, if commercialization stage were based on NPD competitive strategy. It should be noted that the production costs of testing in market comprise about $15 \%$ of all the R\&D stages (Iamratanakul et al, 2011). Wireless telecommunication product line managers in China showed that, all Changes during product life and product development will be far easier, if NPD team for new products in company localizes technology.

\section{Literature review}

\subsection{New product development (NPD)}

NPD process is a set of activities and platforms of development in different stages, in order to produce products for available market and make partial or general modifications or changes in products (Coooper, 1990). There is a common classification represented by counseling center of Booz, Allen and Hamilton (Booz, Allen and Hamilton, 1982) for this definition. This classification is done to identify the freshness of product and is mentioned here by order:

i. New to the world: invention of new products compared to available ones, like Polaroid cameras, first laser printer machine.

ii. New category entries: new products that are going to be produce for the first time by the companies, however they are not new for the market.

iii. Development of the product lines: products that are represented to available market by new product lines. 
iv. Product improvement: modified products that can be introduced as new products. In fact, nowadays products are all modified in kind.

v. Repositioning: to find new utilizations of products. In other words, entrance of new product to new market.

According to these definitions and classifications of new product, there are variables that are not accepted as new products but as product development. They consist of new to the world, product distribution network, and modification to packaging or method of producing product (Crawford, 2002). In most industries, successful development and trading products are implemented by competitive approaches and considering major sufficiency of the firm. In addition, development or growth depends strongly on ability to introduce new products to markets in the right time (Cooper \& Edjett, 2005).

\subsection{Key Success Factors}

The KSFs in NPD include formulating proposals related to product differentiation, re-developing filtering tasks, hearing the voice-of-the-customer, sharply defining product features and benefits, resourcing, successfully executing ideas, indentifying go/kill points, creating project teams, resourcing strength, adopting international orientation and encouraging the active involvement of senior management (Cooper and Edgett, 2006). Research on KSFs for successful NPD indicates that any one of the success factors are neither sufficient nor necessary for success, and a few major groups of KSFs represent some amount of independence in influencing success versus failure (Cooper \& Kleinschmidt, 2007; Di Benedetto, 1999).

Cooper et al (2005) have suggested that the majority of researchers focus on Key Success Factors (KSF), which cause failure or success in product development. Exploring, extracting and understanding the causal relationship among NPD, KSFs and performance outcomes are significant to enterprise product strategies. However, many studies focus on exploring what KSFs are and how they affect the outcomes. These researches for NPD process skimmed by Cooper (2005) in two aspects:

- Appropriate orientation in market, paying attention to the market, considering product and customer as vital.

- Focusing on representing a global product, one international orientation in designing processes and market development.

\subsection{NPDM Theory and Research Hypotheses}

The first applicable model in NPD is Cooper's (1990) NPD model which is focused on by Kotler and Armstrong (2001) too. Moreover, because our products in SHOKA are based on this model, we considered this model as the base of our study. However, there are other models like five-stage model of Saddle et al (1992) or Rainey's model (2005) of product development. Cooper $(1990,1993)$ stage- gate model is divided into 6 stages, which are mentioned here in order: idea gathering, idea screening, idea developing, designing products, product examining and launching. In this research, the researchers gathered all indicators of 
six-stage by secondary studies and by interviewing the managers and considering their opinions. More explanations will be provided in the Methodology section of the study.

Four key factors are important in NPDM process. These factors are; marketing, technology, commercialization and NPD' team. Accordingly, the following hypothesis was developed:

$\left(H_{1}\right)$ : Marketing is the main key factor among other factors of NPDM process.

\subsubsection{Team in NPDM process}

The most effective factor is related to the product development team. However, there are many factors to be considered when managers are going to make decisions, but these factors are divided into 2 categories, internal and external. Here we can mention indicators like making team, motivating team members, screening ideas, and considering rival's politics, which are parts of managers' job in this approach (Doering \& Parayre, 2000; Keizer et al, 2002). Knowledge and risking on decision-making are the most important factors in managing team; although, good management could cause success in executive approaches of differential plans of NPD (Crawford \& Benedetto, 2006). All affective factors are different from type of organization and management approaches. Preliminary interview from SHOKA managers showed using counselors outside the company and arranging meetings with managers of other sections and having appropriate information system can facilitate our success in NPD approach, but indicators like personnel's responsibility, their morale status (Christensen \& Bower, 1996; Keizer et al, 2002), job motivation and their ability to risk are important in managing attitudes of managers about products launch (Griffin, 2002). So, we could say:

\section{$\left(\mathrm{H}_{2}\right)$ : Being a committed team member is the highest important factor in NPD'TEAM.}

\subsubsection{Marketing in NPDM process}

Kotler (2005) believes that the marketing is a process to identify, predict, create and fulfill the needs that customers require for products and services (Kotler \& Armestrang, 2006). In 1952, Neil Borden created the concept of Marketing Mixes (MM), which is the combination of elements and its goal is responding to the market's requirements. This concept was completed by McCarthy and summarized into four-main-factor, which are known as $4 \mathrm{P}_{\mathrm{s}}$ (Baker, 2000). Marketing Mixes is indicated as a set of controllable tools an appropriate combination of which is used in marketing plans. According to market's requirements in Anssof's model, and competitive model of Porter, Models and strategies of product development are considered as a base model for new product development planning (Sarmad-saiyidi, 2007). The process of NPDM is formed based on the customer's requirements; therefore, its critical indicators consist of: market growth, demand, procedures of entrance to the market (Kotler \& Armstrong, 2001; Mu et al, 2008), Products replacing, product advantages, shortest lead time, and problems may be encountered (Tarazof \& Blagoevski, 2000; Kotler \& Armestrang, 2006; Cooper \& Schendel, 2003). Therefore, their Key indicators in marketing factor are considered in the SHOKA CO. too, so we could say:

$\left(\mathrm{H}_{3}\right)$ : Commitment to customer needs is the highest important factor in marketing. 


\subsubsection{Technology in NPDM process}

Technology is the combination of two Greek words: "Techne" which means anything which does not exist in nature and "Logie" which means anything which is based on logic and reason. Technology is the practical use of knowledge and tools to help humankind (Tarogh, 2011). Due to the innovations in industries changes, development and technology adaptation are very important in product innovation. According to functional researches, following indicators is important in NPD productions technology, production an optimum time for commercialization, replacing technology for NPD (Rosenbloom \& Cusumano, 1989), time for replacing new technology, technology stability, products designing and testing in different stages of production by computers (CAD, CAM) (Tarazof \& Blagoevski, 2000) and sharing similar NPD Team beliefs and being in agreement with customer need and technology management. Therefore, it seems that:

$\left(\mathrm{H}_{4}\right)$ : manager consultation with technological and operational group on selecting technology for the production of new products has the highest importance compared to the other indices.

\subsubsection{Commercialization in NPDM process}

Commercialization is the process or cycle of introducing a new product into the market. NPD lunching process in market strategy must be compatible and manageable and minimize internal and external risks. Generally, we could classify external and internal risks in trading into internal and external categories (Barclay et al, 2000):

Internal criteria eg.; investment output, deviating from average industry and timetable for production and External criteria eg.; like economical inputs, components' data and customers' attitudes about the product.

Therefore, following a systematic process, considering environmental changes and hope for perpetuity of companies make these conditions effective in improving this process and have characteristics such as responsiveness, competence, quickness, and flexibility. According to the attitudes of SHOKA's managers, if we do not have an appropriate strategy in market, we will not be successful in marketing and with regard to the global competition, this external factor is crucial for the company. Moreover, all internal factors must be planned and managed very carefully in order to provide new product commercialization for market penetration and increasing market's share. There are some main criteria on the base of which many researchers focus on to commercialize the products like: marketing strategy with competitive approach, flexibility and considering customers' requirements for product (Milton \& Griffin, 1996; Anssof, 1957) NPV and ROI indicators (Griffin, 2002; Cooper \& Edjett, 2005). Moreover, other important and effective elements of commercialization strategy are beliefs and concepts of customers about kinds of product innovation (Tudor \& Alin, 2003). Consequently, it seems that: $\left(H_{5}\right)$ : flexibility and concern for the customers' requirements in the production of the new products are more important than the other indices. 


\section{Methodology}

\subsection{Data collection stages}

In the current study, the data were collected through a multi-stage procedure including in-depth field questionnaires and interviews with SHOKA's manager in manufacturing, research, financial, strategic and marketing department. After extensive literature review, the researchers adapted and synthesised the NPD success factors which were identified by previous researches such as Balachandra and Friar (1997), Calantone and Cooper (1981), Calantone et al. (1996), Cooper (1979, 1999, 2005), Cooper and Kleinschmidt (1995), Ernst (2002), Lester (1998), Lynn et al. (1999), Spivey et al. (1997), Song and Parry (1994, 1997), etc. Finally, the analyzed data indicated that many successful factors, which have been proposed by previous studies for NPD, were effective in the current study, too. These factors vary substantially under different development and firm contexts. Moreover, the methods adopted by existing research are quite different, thus providing surprisingly non-convergent results. Generally, this study was completed in three steps:

Step 1: at first, the researchers prepared some interviews that lasted for about 30-45 min, and then a panel of 10 prominent managers from production, Marketing, R\&D, technology and financial department were invited to assist in developing the criteria of success factors for NPD. According to the related literature, the researchers could identify four key success factors (marketing, technology, commercialization and NPD's team) that were summarized in accordance with 37 indicators and a number of prepared questionnaires.

Step 2: All indexes were listed by Delphi technique and formed into a questionnaire and were given randomly to 12 managers and experts in the NPD related departments. These managers added any other important factors they believed to be important for NPD. Open-ended in-depth interviews were conducted at the same time. Managers read the listed factors and discussed with the researchers in detail about the reasons of the importance of these factors. The managers were required to score, on a Likert scale from [1 to 5], the importance of the key success factors in each stage of the NPD process, with five representing the most important. Therefore, the validity and reliability of the questionnaire was measured through Cronbach's alpha test. The results confirmed the reliability and the validity of this questionnaire.

Step 3: through analyzing the obtained data from the questionnaire and calculating the mean score of each criterion in second step, the researchers identified five main indicators from each KSF on NPDM. Then, the last questionnaire was prepared with AHP technique and was distributed among 20 NPD decision maker managers in SHOKA with a cover letter. Finally, the results of the questionnaire were analyzed using Expert choice software.

\subsection{Data Analysis and Findings}

From results of the steps 1 and 2 and in order to make them more comprehensible the researchers proposed soma crucial factors, which are elaborated more in Table 1. These factors are: Technological (TECH) with 10 indicators, Marketing (MAR) with 10 indicators, Commercialization (COM) with 10 indicators, NPD'S Team Management (TEAM) with 9 


\section{Macrothink}

indicators. The mean score, variance, value of average importance ( $\min \& \max$ ) and reliability for each of the criterion were measured. The outcomes of Total Cronbach's alpha confirmed the reliability of the pre-test. The reliability coefficient turned out to be 0.716 .

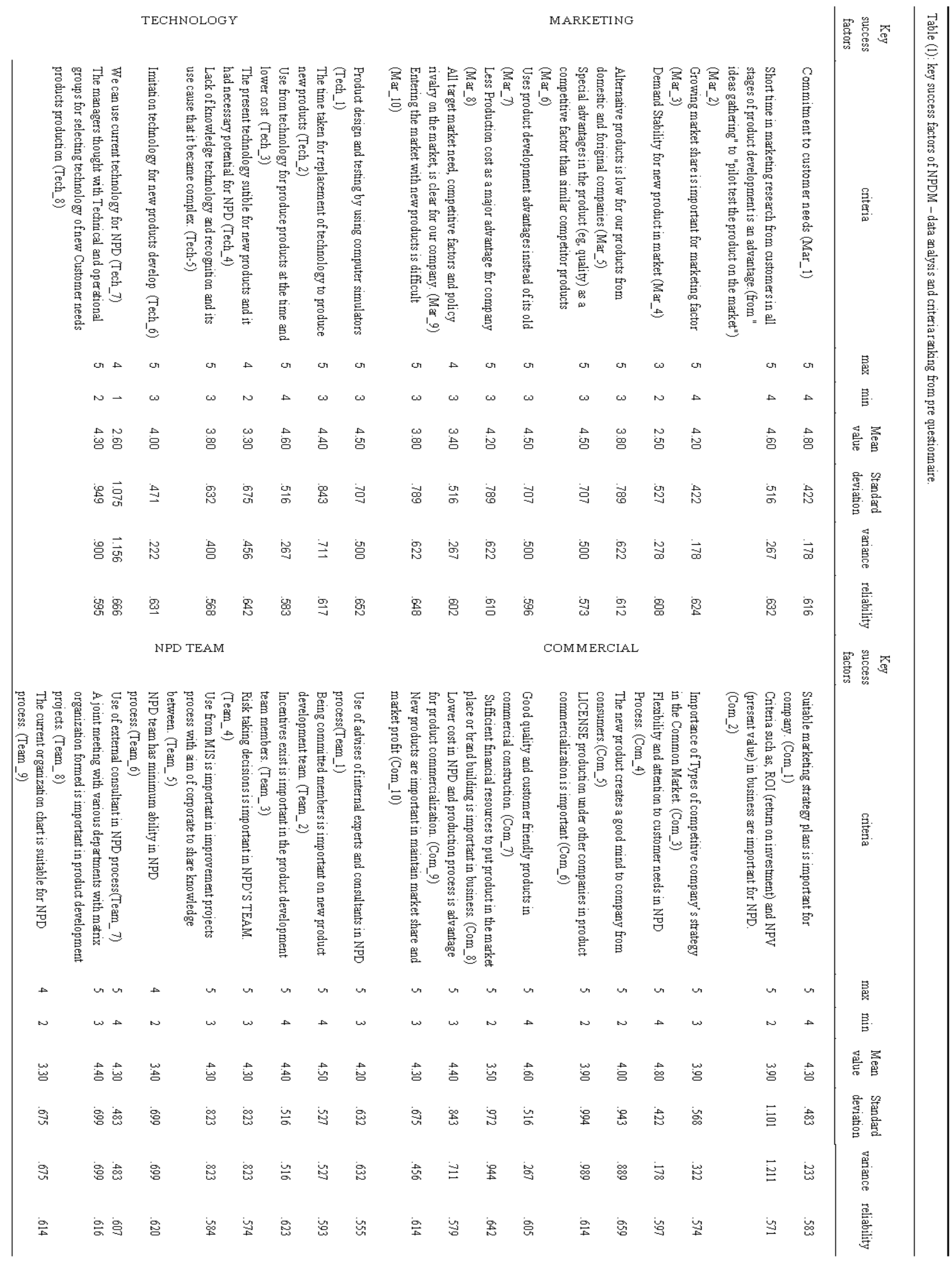


According to the Delphi questionnaire (first questionnaire in table 1) and decision making hierarchy tree (figure 1), the key success criteria on NPDM in SHOKA was selected. Then AHP questionnaire was designed and 20 experts in SHOKA were surveyed and the obtained data were analyzed by expert choice software and the gaps in NPDM processes were evaluated. Table (2) showed descriptive statistics of AHP questionnaire in SHOKA.

Table 2. Descriptive Analysis Of Experts In SHOKA, CO (N=20)

\begin{tabular}{|c|c|c|c|c|c|}
\hline \multirow{2}{*}{ Organizational Position } & Middle manager & 14 & & Under graduated & 2 \\
\hline & Top Manager & 6 & Education & graduated & 8 \\
\hline \multirow{6}{*}{ Work Experience } & & & & Post Graduated & 10 \\
\hline & Under 3 Years & 1 & \multirow{5}{*}{ Department } & & \\
\hline & $3-5$ Years & 3 & & Marketing & 3 \\
\hline & 5-8 Years & 4 & & Research Institute & 8 \\
\hline & 8- 10 Years & 6 & & Financial & 3 \\
\hline & Higher 10 Years & 6 & & Production & 6 \\
\hline
\end{tabular}

\section{Weights}

Group Analytical hierarchy process is one of the most famous methods of MADM, which was innovated by Tomes. L. Saati in 70s. This method could be used whenever decision making faced some other options and decision making criterions. In AHP, decision maker starts his activities by providing hierarchy tree. This tree shows analogous factors and assessable options of opponents. Then by AHP approach, we can determine weight of each factor in the course of opponents' options. Finally, AHP incorporates resultant matrix in such a way that optimum decision will be made. According to Saati and Vargas (2001), if CR<0/1, then AHP matrix will be compatible. When CR is greater than the above-mentioned value, decision maker should revise his decisions. The output results were demonstrated according to the decision-making hierarchy tree. In Table 3, key factors on NPDM shows that, in NPDM team management, there is an important gap between the current and the ideal conditions. Marketing is important in each condition and commercialization policy is more acceptable in the ideal condition. Consequently, the first hypothesis was proved. 


\section{Macrothink}

Table 3. Key Success Factors in NPDM in SHOKA. CO

\begin{tabular}{|l|l|l|l|}
\hline $\begin{array}{l}\text { Key Critical Success } \\
\text { Factor }\end{array}$ & & $\begin{array}{l}\text { Normalized weights for ideal } \\
\text { condition }\end{array}$ & $\begin{array}{l}\text { Normalized Weights For Present } \\
\text { Condition }\end{array}$ \\
\hline Technology & TECH & 0.22 & 0.20 \\
\hline Marketing & MAR & 0.39 & 0.37 \\
\hline Commercialization & COM & 0.23 & 0.22 \\
\hline NPD's team & TEAM & 0.21 & 0.16 \\
\hline Consistent Ratio index for ideal condition and present condition is 0.02 (CR=0.02). \\
\hline
\end{tabular}

Second level of criteria analysis is similar to the criteria of key NPDM factors. The outcomes are indicated in Tables 4, 5, 6 and 7.

Among technological indicators in table 4 "product design and testing by using computer simulators" has minimum importance in the present condition and criteria of "manager thought with technological and operational group for selecting technology of new customer needs products production" is important in the present and the ideal conditions, therefore the second hypothesis was accepted. 
Table 4. Key Criteria For Technological in NPDM

\begin{tabular}{|l|l|l|l|}
\hline \multicolumn{2}{|l|}{ Key Critical effective on technology } & $\begin{array}{l}\text { Normalized Weights } \\
\text { For Ideal Condition }\end{array}$ & $\begin{array}{l}\text { Normalized Weights For } \\
\text { Present Condition }\end{array}$ \\
\hline $\begin{array}{l}\text { Use from technology for produce products at } \\
\text { the time and lower cost }\end{array}$ & TECH-1 & 0.224 & 0.183 \\
\hline $\begin{array}{l}\text { Product design and testing by using computer } \\
\text { simulators }\end{array}$ & TECH-2 & 0.243 & 0.14 \\
\hline $\begin{array}{l}\text { The time taken for replacement of technology } \\
\text { to produce new products }\end{array}$ & TECH-3 & 0.159 & 0.213 \\
\hline $\begin{array}{l}\text { The managers thought with Technical and } \\
\text { operational groups for selecting } \\
\text { technology ... TECH-4 }\end{array}$ & 0.251 & 0.271 \\
\hline $\begin{array}{l}\text { Imitation technology for new products } \\
\text { develop }\end{array}$ & TECH-5 & 0.123 & 0.193 \\
\hline Consistent Ratio index for ideal and present conditions are $0.09(\mathrm{CR}=0.09) \& 0.02(\mathrm{CR}=0.02)$. \\
\hline
\end{tabular}

According to table 5 commitments to customer needs is an important criterion in ideal and present conditions; therefore the third hypothesis was proved. Experts opinion in table 5 shows that "Special advantages in the product (e.g., quality) as a competitive factor than similar competitor products" is less important in comparison with other marketing factor in NPDM process so we should consider this criterion in decision-making.

Table 5. Key Criteria For Marketing In NPDM

\begin{tabular}{|l|l|l|l|}
\hline Key Critical effective on Marketing & & $\begin{array}{l}\text { Normalized Weights } \\
\text { For Ideal Condition }\end{array}$ & $\begin{array}{l}\text { Normalized Weights For } \\
\text { Present Condition }\end{array}$ \\
\hline Commitment to customer needs & MAR-1 & 0.187 & 0.297 \\
\hline $\begin{array}{l}\text { The advantage of a short time in marketing } \\
\text { research at all stages of product development }\end{array}$ & MAR-2 & 0.187 & 0.201 \\
\hline $\begin{array}{l}\text { Special advantages in the product (e.g., } \\
\text { quality) as a competitive factor than similar } \\
\text { competitor products }\end{array}$ & MAR-3 & 0.37 & 0.197 \\
\hline $\begin{array}{l}\text { uses product development advantages instead } \\
\text { of its old }\end{array}$ & MAR-4 & 0.145 & 0.168 \\
\hline less Production cost as a major advantage & MAR-5 & 0.111 & 0.137 \\
\hline Consistent Ratio index for ideal and present conditions are $0.03(\mathrm{CR}=0.03) \& 0.01(\mathrm{CR}=0.01)$. \\
\hline
\end{tabular}

Analysis of the forth hypothesis showed (Table 6) that there is an undesirable gap in commercialization in relation to "unsuitable marketing strategy plans is important for company". "Lower cost in NPD and production process is advantageous for product 


\section{Macrothink}

Journal of Management Research

ISSN 1941-899X 2012, Vol. 4, No. 3

commercialization" is less important and "flexibility and attention to customer needs in NPD Process" is the most important criterion in NPD commercialization. Therefore, this hypothesis was approved.

Table 6. Key Criteria for Commercialization In NPDM

Key Critical effective on Commercialization

Flexibility and attention to customer needs in NPD Process

Good quality and customer friendly products in commercial construction

lower cost in NPD and production process is advantage for product commercialization

New products are important in maintain market share and market profit

suitable marketing strategy plans is important for company

\section{Normalized Weights Normalized Weights For For Ideal Condition Present Condition}

$\begin{array}{lll}\text { COM-1 } & 0.237 & 0.302\end{array}$

$\begin{array}{lll}\text { COM-2 } & 0.256 & 0.241\end{array}$

$\begin{array}{lll}\text { COM-3 } & 0.09 & 0.13\end{array}$

$\begin{array}{lll}\text { COM-4 } & 0.129 & 0.186\end{array}$

$\begin{array}{lll}\text { COM-5 } & 0.279 & 0.141\end{array}$

Consistent Ratio index for ideal and present conditions are $0.01(\mathrm{CR}=0.01) \& 0.03(\mathrm{CR}=0.03)$.

Analysis of NPD Team factor in NPDM process, according to table 7, showed that the index of "Risk taking decisions is important in NPD'S TEAM" has the greatest gap. In addition, "Use from MIS is important in improvement projects process with aim of corporate to share knowledge" is less important, so "being committed members that is important on new product development team" is more valuable in two conditions among other factors therefore the fifth hypothesis was approved. 
Table 7. Key Criteria for NPD' Team In NPDM

\begin{tabular}{|c|c|c|c|}
\hline \multicolumn{2}{|l|}{ Key Critical effective on NPD' Team } & $\begin{array}{l}\text { Normalized Weights } \\
\text { For Ideal Condition }\end{array}$ & $\begin{array}{l}\text { Normalized Weights } \\
\text { For Present Condition }\end{array}$ \\
\hline $\begin{array}{l}\text { Being committed members is important on } \\
\text { new product development team }\end{array}$ & TEAM-1 & 0.255 & 0.273 \\
\hline $\begin{array}{l}\text { Incentives exist is important in the product } \\
\text { development team members }\end{array}$ & TEAM-2 & 0.248 & 0.259 \\
\hline $\begin{array}{l}\text { Joint meetings with various departments with } \\
\text { matrix organization formed is important in } \\
\text { product development projects }\end{array}$ & TEAM-3 & 0.196 & 0.221 \\
\hline decisions Risk is important in NPD team & TEAM-4 & 0.173 & 0.122 \\
\hline $\begin{array}{l}\text { Use from MIS is important in improvement } \\
\text { projects process with aim of corporate to share } \\
\text { knowledge between members }\end{array}$ & TEAM-5 & 0.128 & 0.125 \\
\hline
\end{tabular}

The final level of decision-making tree shows that in Table 8, all the indexes were subject to Paired comparisons. Table 8 represents tactics. In conclusion and suggestions section, we will provide more explanations. 
Table 8. Comparative All Key NPDM Criteria in SHOKA. CO

\begin{tabular}{|c|c|c|}
\hline $\begin{array}{l}\text { Key criteria in NPDM process } \\
\text { (last level of diction making tree) }\end{array}$ & $\begin{array}{l}\text { N.W For Ideal } \\
\text { Condition }\end{array}$ & $\begin{array}{ll}\text { N.W } & \text { For } \\
\text { Present } & \\
\text { Condition } & \end{array}$ \\
\hline Use from technology for produce products at the time and lower cost & 0.056 & 0.04 \\
\hline Product design and testing by using computer simulators & 0.062 & 0.031 \\
\hline The time taken for replacement of technology to produce new products & 0.041 & 0.047 \\
\hline $\begin{array}{l}\text { The managers thought with Technical and operational groups for selecting } \\
\text { technology of new Customer needs products production }\end{array}$ & 0.064 & 0.059 \\
\hline Imitation technology for new products develop & 0.032 & 0.042 \\
\hline Commitment to customer needs & 0.074 & 0.09 \\
\hline $\begin{array}{l}\text { The advantage of a short time in marketing research at all stages of product } \\
\text { development }\end{array}$ & 0.073 & 0.061 \\
\hline $\begin{array}{l}\text { Special advantages in the product (eg, quality) as a competitive factor than } \\
\text { similar competitor products }\end{array}$ & 0.146 & 0.061 \\
\hline uses product development advantages instead of its old & 0.057 & 0.051 \\
\hline less Production cost as a major advantage for company & 0.044 & 0.041 \\
\hline Flexibility and attention to customer needs in NPD Process & 0.048 & 0.068 \\
\hline Good quality and customer friendly products in commercial construction & 0.065 & 0.054 \\
\hline $\begin{array}{l}\text { lower cost in NPD and production process is advantage for product } \\
\text { commercialization }\end{array}$ & 0.02 & 0.029 \\
\hline New products are important in maintain market share and market profit & 0.026 & 0.042 \\
\hline suitable marketing strategy plans is important for company & 0.061 & 0.032 \\
\hline Being committed members is important on new product development team & 0.035 & 0.065 \\
\hline Incentives exist is important in the product development team members & 0.035 & 0.063 \\
\hline $\begin{array}{l}\text { Joint meetings with various departments with matrix organization formed is } \\
\text { important in product development projects }\end{array}$ & 0.029 & 0.05 \\
\hline Risk taking decisions is important in NPD team & 0.061 & 0.044 \\
\hline $\begin{array}{l}\text { Use from MIS is important in improvement projects process with aim of } \\
\text { corporate to share knowledge between members }\end{array}$ & 0.061 & 0.033 \\
\hline
\end{tabular}

\section{Conclusion}

This study aimed at investigating multiple criteria decision-making techniques in New Product Development Management (NPDM). The data, which were obtained through interview and analyzed. The results of this study suggested that a new management approach is considered as an effective factor in reinforcing the efficiency of that approach. Furthermore, it is concluded that this approach would identify major factors of managerial tactics, which 
result in changes in NPD strategies.

Analytical hierarchy process for technology, marketing, commercialization and new product development team key factors showed all key factors to be less than the ideal status. So, in order to achieve the ideal situation, decision makers are supposed to emphasize more on the main applicable factors and to provide appropriate solutions which are much closer to the company' tactics of ideal situation. In this case, the most important factor is commercialization and this factor is the closest to the ideal situation than the others. Therefore, this could be considered as a strong point for the company than the other factors that the researchers examined during the study.

Pair comparison technological criteria showed that "“'Imitation technology for new products develop», "The managers thought with Technical and operational groups for selecting technology of new Customer needs products production»" and "The time taken for replacement of technology to produce new products" are closer to ideal situation but "Product design and testing by using computer simulators» and "Use of technology for production at the time and lower cost»" specially the first one, among other key factors in the new production technology, is not in accordance with ideal conditions. This problem was not the desirable condition of NPD management process in SHOKA.

Experts in SHOKA were satisfied with Marketing criteria condition but "the company Special advantages in the product (e.g., quality) as a competitive factor than similar competitor products» must be improved, so the researchers proposed some tactical approaches to enhance this key factor in NPD decision making process.

Commercialization indicators factor analysis showed that "Flexibility and attention to customer needs in NPD Process», "Lower cost in NPD and production process is an advantage for product commercialization», from the manager's viewpoint, would possess a good position in SHOKA and the process of decision making must be improved. On the other hand, "Good quality and customer friendly products in commercial construction", "New products are important in maintain market share and market profit» are related to "unsuitable marketing strategy plans that are important for company», so the researchers attempted to change this weakness to ideal condition because these criteria are competitive and increase market flexibility strategies.

NPD team members and risk takers (table.7) are in good condition. Since NPD team criteria are important in new product process, tactical decision making for this factor with content analyses is presented in the suggestion section.

According to the latest level decision making tree, as is illustrated in table 8 , all criteria rankings are related to each other. Results showed that in the current condition "Commitment to customer needs (average mean weight 0.90) $»$ is the most important index among the other indices and "Lower cost in NPD» and "production process is an advantage for product commercialization (average mean weight 0.029)" are not so important among the other indicators. In an ideal condition, "Special advantages in the product (e.g. quality) as a competitive factor than similar competitor products (average mean weight 0.146 ) » have the 
highest importance from the perspective of experts in the SHOKA Company. Also this group believes that Risk taking decisions is important in NPD's team and Use of MIS is important in improving projects with the aim of corporation to share knowledge (mean weight 0.016 ) the least important in NPD process. All comparative criteria ranking have been shown in Table 8.

\subsection{Suggestions}

The following suggestions and recommendations are the results of content analysis and matched by findings to decrease the gap between the current and ideal critical success factors:

1. Computer-based products testing (test piece to piece before assembling; test the quality of the products based on the voice of the customer with an after sell service approach.

2. In choosing the production technology, although managers agree with the technology which is based on imitation, all experts believe that in choosing this approach, time and cost savings are fully optimized for transferring technology, therefore the following recommendations are put forward:

- Creating team collaboration with R\&D unit for technology modification and adaptation of new technology for new products.

- Providing idea database system for idea gathering and screening.

3. Extension of marketing department cooperation with NPD team to cover weaknesses of business plans.

4. Products benchmarking with other competitors in the field of design, quality, level of standard to arrange new products' organizational standards.

5. The last important suggestion is creating NPD division in marketing department as matrix structure because the purpose of the product development team is organizing NPD process, management and developing new plans and implementation of NPD strategies. Therefore, we recommend this structure based on figure. 1 for this company. 


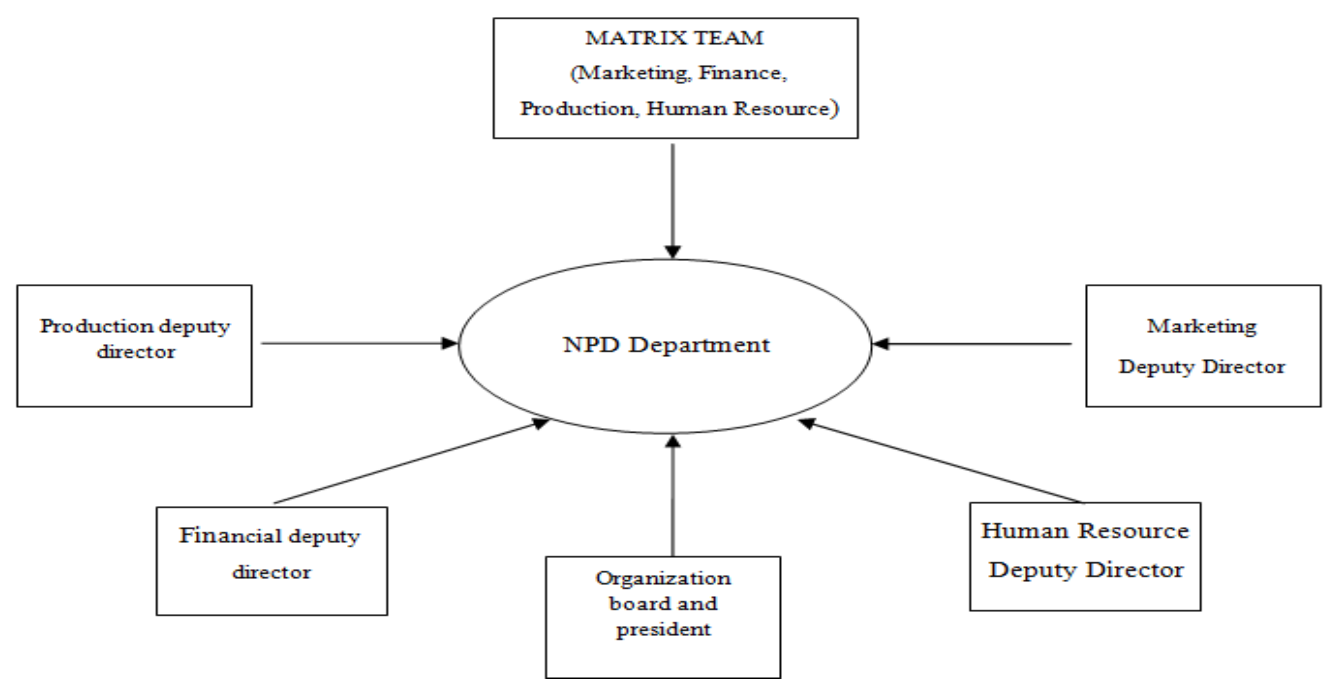

Source: researchers finding

Figure 1. Create NPD Department in SHOKA. Co

\section{References}

American Productivity and Quality Center. (2003). Improving New Product Development Performance and Practices. American Productivity \& Quality Center, Houston, TX.

Ansary, M., \& Mamaghani, A.R. (2011). Strategic Management of New Product development Management from idea to implementation. Industrial Management Association.

Anssof, I. (1957). Compare Strategy-Strategy for Diversification. Harvard Business Review.

Baker, M.J. (2000). Marketing strategy and management. Third Edition, MacMillan press LTD London, 216.

Barclay, I, Dann, Z., \& Holord, P. (2000). New product development. IRWIN Publishes.

Booz, Allen, \& Hamilton. (1982). New Product Management for the 1980s. Booz, Allen \& Hamilton Inc., New York (NY).

Christensen, C.M., \& Bower, J.L. (1996). Customer power, strategic investment, and the failure of leading firm. Strategic Management Journal, 17(3), 197-281. http://dx.doi.org/10.1002/(SICI)1097-0266(199603)17:3<197::AID-SMJ804>3.0.CO;2-U

Crawford, C. M. (2002). New product management. Irwin. fifth Edition, 9.

Cooper, A., \& Schendel, D. (2003). Strategic response to technological threats. Business Horizons, 19(1), 61-69. http://dx.doi.org/10.1016/0007-6813(76)90024-0

Cooper, R. G. (1997). The dimensions of industrial new product success and failure. Journal of Marketing, 43(3), a 93-103 \& b 60-74.

Cooper, R. G. (1990). Stage-gate systems- A New Tool for Managing New Products. 
Business Horizons, 33 (3), 44-54. http://dx.doi.org/10.1016/0007-6813(90)90040-I

Cooper, R.G., \& Kleinschmidt E. J. (2007). Winning Businesses in Product Development: The Critical Success Factors. Res.-Technol. Manage (May-June), 1-15.

Cooper, R. G., \& Edjett, S. T. (2005). Lean, Rapid and Profitable. New Product Development Institute.

Cooper, R. G., \& Edgett, S. J. (2006). Stage-Gate and the Critical Success Factors for New Product Development. Journal of Product development institute, 1-6.

Cooper, R. G. (1993). Winning at New Products: Accelerating the Process from Idea to Launch. Publish by Peruses Books, 2.

Crawford, M., \& Benedetto, Di. A. (2006). New Product Management, (8th ED), McGraw-Hill, (NY), 9.

Di-Benedetto, C. A. (1999). Identifying the Key Success Factors in New Product Launch. Journal of Product Innovation Management, 16: 530-544. http://dx.doi.org/10.1016/S0737-6782(99)00014-4

Doering., D.S., \& Parayre, R.(2000). Identification and assessment of emerging technologies. In: Day. Managing Emerging Technologies, Wiley, New York, 75-98.

Griffin, A. (2002). Product development cycle time for business-to-business products. Industrial Marketing Management, 31, 291-304. http://dx.doi.org/10.1016/S0019-8501(01)00162-6

Hyun, Y. S. (2010). The road to the self-reliance new product development of HYUNDAI motor company. Han Nam University Taejon KOREA, 213.

Keizer, J. A, Halman, J.I.M., \& Song, M. (2000). From experience: applying the risk diagnosing methodology. Journal of Product Innovation Management, 19, 213-232. http://dx.doi.org/10.1016/S0737-6782(02)00138-8

Kotler, P., \& Armstrong, G. (2001). Principles of Marketing. (ninth Ed), Prentice-Hall, 6.

Kotler, P., \& Armestrang G. (2006). Principal of marketing. Bahman Frozandeh (translator), (8th ed), Tehran,Amokhte Publication, Iran.

Iamratanakul, S, Patanakul, P., \& Milosevic, D. (2011). Innovation and factors affecting the success of NPD projects in Toyota: Literature explorations and descriptions. International Journal of Management Science and Engineering Management, 3, 318-322.

Milton, R.D., \& Griffin, G.A.(1996). Castellion and NF. Anschuetz, the PDMA Handbook of New Product Development, John Wiley \& Sons, 73.

Mu, J., Peng, G., \&. Tan, Y. (2007). New product development in Chinese enterprise key successes factors managerial prospective. International Journal of Emerging Marketing, 2(2), 123-143. http://dx.doi.org/10.1108/17468800710739216

Mu, J., Peng, G \& Maclachlan, D.L. (2008). Effect of risk management strategy on NPD 
performance. Technovation, 10(16), 1-10.

Rainey, D. (2005). Product Innovation: Leading Change through Integrated Product Development. Cambridge University Press. New York, (NY). http://dx.doi.org/10.1017/CBO9780511541230

Rosenbloom, R., \& Cusumano, M. (1989). Technological Pioneering. California. Management Review, 29(4), 3-22.

Saaty, T.L., \& Vargas, L.G. (2001). Models, Methods, Concepts \& Applications of the Analytic Hierarchy Process, Kluwer's Academic Publishers, Boston, USA.

Saddle, U., River, N.J, Wheelwright, S.C., \& Clark, K. B. (1992). Revolutionizing Product Development: Quantum Leaps in Speed. Efficiency and Quality the Free Press, New York (NY), 19-23.

Sarmad-saiyidi, S. (2007). Management and Strategic Planning. Heyaat Publication, Tehran, 107-109

Tarazof, A., \& Blagoevski. (2000). Managing NPD process, ESDN Consulting.

Tarogh, K. (2011). Technology Management. Baghery SK (translator), Niroo Technology Institute Publication, Tehran, 114

Tudor, I.F., \& Alin, S. (2003). Key Success Factors in New Product Development Process. The Academy of Economic Studies, 213-124. 